\title{
Relationship between Islamic spirituality and psychological well-being, depression and anxiety
}

\author{
YalnaazLakdawala ${ }^{1}$, Aqsa Qasmi², Cicilia Chettiar ${ }^{3}$ \\ ${ }^{1,2}$ Undergraduate students, \\ ${ }^{3} \mathrm{Head}$, Department of Psychology,ManibenNanavati Women's College, Mumbai. \\ Corresponding author: YalnaazLakdawala \\ Email-yalnaaz.lak@gmail.com
}

\begin{abstract}
Background: This study aims to observe the correlation between Islamic spirituality and psychological well being, along with depression and anxiety.

Methods: The tools used for measuring Islamic spirituality, Psychological well-being, anxiety and depression were Multi-dimensional measure of Islamic spirituality by Dasti\& Sitwat,2014, Scale of psychological well-being by Carol Ryff, GAD- 7 \& PHQ-9 respectively. Convenience sampling technique was used to collect data from 60 participants. The sample includes both the genders over 18 years.

Results: Results indicate a positive correlation between psychological well-being and islamic spirituality and a negative correlation of islamic spirituality with depression and anxiety.

Conclusion:The current study hypothesized no relationship between islamic spirituality and psychological well-being, depression and anxiety. All the null hypotheses were rejected. Thus, a positive correlation between psychological well-being and islamic spirituality and a negative correlation of islamic spirituality with depression and anxiety was observed.
\end{abstract}

Keywords: Islamic spirituality, depression, anxiety, psychological well-being, mental health.

(Paper received $-2^{\text {nd }}$ January 2018, Peer review completed $-8^{\text {th }}$ January 2018)

(Accepted $-16^{\text {th }}$ January 2018)

\section{INTRODUCTION}

Depression is a major public health problem in India, contributing to significant morbidity, disability as well as mortality, along with significant socio economic Losses. Depression is characterized as a mood disorder. According to the International Foundation for Research and Education on Depression (2005), the three main types of depression are major depression, dysthymia, and bipolar disorder. Globally, an 1 estimated 322 million people were affected by depression in 2015 [1]. As per the World Health Organisation's Report "Depression and Other Common Mental Disorders - Global Health Estimates" released in 2017, the estimated prevalence of depressive disorders in India is $4.5 \%$ of the total population [2]. Depression is one of the two diagnostic categories that constitute common mental disorders (CMDs), the other being anxiety disorder [3].

Anxiety is a subjective state of internal discomfort. Dread, and foreboding, which manifests itself in cognitive, behavioral, and physiological symptoms. It is a normal emotion with adaptive value, in that it acts as a warning system to alert a person to impending danger. Anxiety often occurs without conscious or apparent stimulus, which distinguishes it from fear [4]. Cognitive symptoms of anxiety include worrying, impaired attention, poor concentration, and memory problems. Physiological symptoms such as hyperventilation, sweating, diarrhoea, trembling, and restlessness also occur. Anxiety may be focused on a 
specific object, situation, or activity (a phobia) or may be unfocused and expressed as a more general dread [5]. According to WHO's reports in 2017, more than 38 million Indians suffer from Anxiety disorders.

Mental health is an integral part of health and is more than the absence of mental illnesses. It refers to a broad array of activities directly or indirectly related to the mental well-being, prevention of mental disorders, and treatment and rehabilitation of people affected by mental disorders. In India, WHO estimates that the burden of mental health problems is of the tune of 2,443 DALYs per 100,000 population, and the age-adjusted suicide rate per 100,000 population is 21.1 . It is estimated that, in India, the economic loss, due to mental health conditions between 2012-2030 is 1.03 trillions of 2010 dollars [6].

Determinants of mental health and mental disorders include not only individual attributes such as the ability to manage one's thoughts, emotions, behaviours and interactions with others, but also social, cultural, economic, political and environmental factors. Specific psychological and personality factors also contribute towards the vulnerability. Genetic factors also play some role [3].

There is a significant body of literature indicating that religion may influence wellbeing through pathways that are behavioural, psychological, social and physiological and in the wider literature, there is evidence that interventions that include faith are effective in the treatment of depression. A review of evidence, across diverse religious groups suggests that religious activities including private prayer and collective worship can contribute to wellbeing and decrease isolation [7].

Religious involvement is also common today, with surveys showing that a significant proportion of the world's population has religious beliefs and practices that are important to daily life. A survey of developed countries by Angus Reid Strategies involving 5,800 adults in Australia, Britain, Canada, China, Egypt, France, Germany, India, Israel, Italy, Japan, Lebanon, Mexico, Russia, Saudi Arabia, South Africa, Republic of Korea, Spain, Turkey, and the United States found that $48 \%$ of respondents said religion is a "very important" component of their daily lives [8].

Within the psychology of religion, attention has been directed to attachment to God as an important new field for investigating individual differences in spirituality (Hill, 2005). Spirituality is defined as individual, subjective spiritual experience - in many cases, this refers to the individual's experience during religious events, but it may also refer to non-religious feelings of being connected to God or in tune with creation, regardless of religious participation [9].

Research suggests that spirituality is not only negatively associated with symptoms of depression but also aids in its treatment [10]. Apart from depression, spirituality helps in coping and facilitates adjustment in the face of trauma. Spirituality also assists in reinterpretation of self in the face of distress and sufferings, and promotes hope, purpose and meaning in life [12]. Furthermore, it is found that spirituality lowers anxiety, relieves stress and enhances resilience. It also helps in forming a positive attitude toward life and leads to greater perceived social support [13].

The importance of spirituality in mental health has been further emphasized by the inclusion of the V code in the DSM-V relating to religious and spiritual problems [14]. The APA (2002) ethical principles of psychologists and code of conduct have also shed light on the importance of role of religious and spiritual issues in counselling and psychotherapy [15].

However, there has been very little systematic study carried out to analyze the concept of spirituality in Islam, which may be different from other religions [12].

Islamic worldview, which is thought to be important in the operationalization of the religious/spiritual construct, has unique characteristics that are different from other religions. Therefore, operationalization of the religious construct representing the unique aspects of Islamic spirituality should be studied to understand the Islamic Religio-spiritual philosophical framework [16].

The concept of spirituality/religiosity in Islam is central to the lives of many Muslims. Islamic perspective of spirituality emerges from religion [12]. Rassool explains that in Islam there is no concept of spirituality except when seen in the light of religion, or Islamic law/shariah [17]. Islamic law mainly is derived from the Qur'an and the prophetic traditions known as hadith and is taken as a source of guidance for Muslims in every aspect of life. Islam, therefore, is a deen (way of life) yielding guidelines for its followers in each domain of life. It is not related to one aspect of an individual but is spread across the whole being [18].

The five pillars of Islam include, which characterizes the Islamic practices and a component related to belief are prayer, fasting, alms-giving, Pilgrimage, and testimony of faith [19]. These tenets are believed to 
include benefits for the believers; for example, it has been found that Islamic prayer can help to buffer against stress, enhance personal wellbeing, foster a sense of closeness to God, facilitate problem solving, and promote self-discipline [20].

The Islamic perspective of spirituality is synonymous with nearness to Allah (God) and is manifested through actions focused on seeking Divine pleasure. The strengthening of relationship with the Almighty is considered to be the driving force behind every behaviour [21]. Ghazali (1909) suggested that the alchemy of happiness rests on the quest to know Allah.

\section{Rationale}

As spirituality has come to a point of official recognition in mental health through its inclusion in DSM-V by APA in 2013, the field of psychology and psychiatry comes to understanding the importance of spirituality and religiosity. Various religions have been studied by psychologists with a view to explore the effect or relationship of religiosity with mental health, with most of them pertaining to Christianity. However, very little research has focused on Islamic spirituality and its role in mental health, and even less in the Indian context, where $14.2 \%$ of Muslims reside it becomes important to study the same.

\section{Objectives: \\ - To find out the relationship between Islamic spirituality and depression \\ - To find out the relationship between Islamic spirituality and anxiety \\ - To explore the relationship between Islamic spirituality and psychological well-being Hypotheses \\ $\mathrm{H}_{01}$ : There is no statistically significant correlation between Islamic spirituality and depression \\ $\mathrm{H}_{02}$ : There is no statistically significant correlation between Islamic spirituality and anxiety \\ $\mathrm{H}_{03}$ : There is no statistically significant correlation between Islamic spirituality and psychological well- being}

\section{METHODOLOGY}

\section{Sampling Procedure}

A sample of 60 participants was collected from Mumbai. Convenience sampling procedure was used.

Tool

Multi-dimensional measure of Islamic spirituality was used to measure Islamic spirituality. The scale was developed by Dasti and Sitwat and Cronbach's alpha for each subscale revealed moderate to high ( 0.68 to 0.84) internal consistency. Test-retest results indicated significant high correlation between the scores of each scale with its readministered scores. Scale of psychological well being by Carol Ryff was used with a test retest reliability of 0.82 .

GAD7 was used to measure anxiety. It's reliability was good (Cronbach's alpha $=0.89$ ), a sensitivity of $73.3 \%$ and a specificity of $67.3 \%$. PHQ-9 was used to measure depression. It had high internal consistency and good reliability.

\section{Data Analysis}

Data was analysed using SPSS version 16.0. Pearson's correlation test was applied.

\section{RESULTS AND DISCUSSION}

\section{Demographics}

Majority (55\%) of the population fell under the category of $18-25$ years. Majority $(76.7 \%)$ of the participants were females and $14.3 \%$ were males. Most (46.7\%) of the population were graduates. Forty five percent of the participants had a monthly income between 25,000-50,000 INR. Eighty eight point three percent of the participants reported not facing any chronic disorder and $83.3 \%$ reported not facing any acute illness in the past 6 months. 
Table 1 - Pearson's Correlation and p-value between Islamic Spirituality and Depression

\begin{tabular}{|l|l|l|}
\hline & & Depression \\
\hline Islamic Spirituality & Pearson & -.280 \\
& Correlation & $(.030)^{*}$ \\
& $\mathrm{~N}$ & 60 \\
\hline
\end{tabular}

${ }^{*}$ Significant at $\mathrm{p}<0.05$ level

There was a statistically significant relationship between depression and islamic spirituality. A negative correlation indicates that as the score on islamic spirituality increases, the score on depression decreases. Thus, null hypothesis $\mathrm{H}_{01}$ is rejected. A research conducted by Klukow demonstrated using an independent samples t-test that depressed persons had significantly lower scores of spirituality than non-depressed persons.

Table 2 - Pearson's Correlation and p-value between Islamic Spirituality and Anxiety

\begin{tabular}{|l|l|l|}
\hline & & Anxiety \\
\hline Islamic Spirituality & Pearson & -.385 \\
& Correlation & $(.002)^{*}$ \\
& N & 60 \\
\hline \multicolumn{2}{|c|}{${ }^{*}$ Significant at $p<0.05$ level }
\end{tabular}

There was a statistically significant relationship between anxiety and Islamic spirituality. A negative correlation indicates that as the score on islamic spirituality increases, the score on anxiety decreases. Thus null hypothesis $\mathrm{H}_{02}$ is rejected. A research conducted Ismail and Desmukh displayed a negative correlation between religiosity and anxiety.

Table 3 - Pearson's Correlation and p-value between Islamic Spirituality and Psychological Well-being

\begin{tabular}{|l|l|l|}
\hline & & $\begin{array}{l}\text { Psychological } \\
\text { Well-being }\end{array}$ \\
\hline Islamic Spirituality & Pearson & .392 \\
& Correlation & $(.002)^{*}$ \\
& $\mathrm{~N}$ & 60 \\
\hline \multicolumn{2}{|l|}{ *Significant at $\mathrm{p}<0.05$ level }
\end{tabular}

There was a statistically significant relationship between psychological well-being and Islamic spirituality. A positive correlation indicates that as the score on Islamic spirituality increases, the score on psychological well-being increases. Thus, null hypothesis $\mathrm{H}_{03}$ is rejected. The results of a study conducted by Hafeez and Rafique indicate that psychological wellbeing was significantly predicted by religiosity [22].

\section{CONCLUSION}

Mental health includes both well-being and absence of illness. This study focuses on two aspects of mental illness i.e. depression and anxiety and psychological well-being. The current study hypothesized no relationship between Islamic spirituality and psychological well-being, depression and anxiety. All the null hypotheses were rejected. Thus, a positive correlation between psychological well-being and Islamic spirituality and a negative correlation of Islamic spirituality with depression and anxiety was observed.

The study had a small sample size and convenience sampling technique was used. A more random sample would be suggested for further research. Effect of gender and socio- economic differences can be seen. 


\section{REFERENCES}

1. Ghaderi AR, Kumar GV, Kumar S. Depression, anxiety and stress among the Indian and Iranian students. J Indian Acad Appl Psychol 2009;35(1):33-7.

2. Jamison DT, Murray CJ. Global burden of disease and risk factors. Lopez AD, Mathers CD, Ezzati M, editors. New York: Oxford University Press; 2006.

3. World Health Organization. Let's talk about depression. WHO: Geneva: 2017.

4. Sahranavard M, Hassan S. Investigation of Construct Validity of State Anxiety Inventory among Iranian 8th Grade Students. Asian J Appl Sci 2015;8(1):63-70.

5. Bhatia V, Tandon RK. Stress and the gastrointestinal tract. J Gastroenterol Hepatol 2005;20(3):332-9.

6. World Health Organization. Mental health in India. WHO; 2018.

7. Meer S, Mir G. Muslims and depression: the role of religious beliefs in therapy. J Integrat Psychol Therapeut 2014;2(1):2-8.

8. Bonelli R, Dew RE, Koenig HG, Rosmarin DH, Vasegh S. Religious and spiritual factors in depression: review and integration of the research. Depress Res Treat 2012;15:120.

9. Klukow KJ. Depression and evangelical Christian spirituality: Exploring a theoretical model (Doctoral dissertation, The University of Tennessee at Chattanooga); 2012.

10. Josephson AM, Peteet JR, editors. Handbook of spirituality and worldview in clinical practice. American Psychiatric Publishing : New York ; 2008.

11. Cornah D. The impact of spirituality on mental health: A review of the literature. Mental Health Foundation; 2006.

12. Dasti R, Sitwat A. Development of a multidimensional measure of islamic spirituality (MMIS). J Muslim Mental Health 2014;8(2):30-5.

13. Pardini DA, Plante TG, Sherman A, Stump JE. Religious faith and spirituality in substance abuse recovery: Determining the mental health benefits. J Subs Abuse Treat 2000;19(4):347-54.

14. Diagnostic and statistical manual of mental disorders (DSM-5). American Psychological Association (APA); Washington DC: American Psychiatric Publishing; 2013.

15. American Psychological Association. Ethical principles of psychologists and code of conduct. Amer Psychol 2002;57(12):1060-73.

16. Krauss SE, Hamzah AH, Suandi T, Noah SM, Mastor KA, Juhari R, Manap J. 'The Muslim ReligiosityPersonality Measurement Inventory (MRPI)'s Religiosity Measurement Model: Towards Filling the Gaps in Religiosity Research on Muslims,". Pertanika Journal of Social Sciences \& Humanities 2005;13(2):131-45.

17. Rassool GH. The crescent and Islam: healing, nursing and the spiritual dimension. Some considerations towards an understanding of the Islamic perspectives on caring. J Adv Nurs 2000;32(6):1476-84.

18. Iqbal M. The reconstruction of religious thought in Islam. Stanford University Press; 2013.

19. Hamdan A. A comprehensive contemplative approach from the Islamic Tradition. Contemplative practices in action: Spiritual Meditat Health 2010:122-42.

20. Henry HM. Spiritual energy of Islamic prayers as a catalyst for psychotherapy. J Relgion Health 2015;54(2):387-98.

21. A'laMaududi A, Ahmad K. The Islamic Way of Life. Islamic Foundation; 2001.

22. Hafeez A, Rafique R. Spirituality and Religiosity as Predictors of Psychological Well-Being in Residents of Old Homes. Dialogue (Pakistan) 2013;8(3);30.

\footnotetext{
$* * * * * * * * * * * * * * * * * * * * * * * * * * *$

Acknowledgements - Special Thanks to Dr. Cicilia Chettiar for her constant guidance and support throughout.

$$
\begin{gathered}
\text { Conflict of Interest - Nil } \\
\text { Funding - Nil }
\end{gathered}
$$
}

